\title{
CONTRIBUTION TO THE KNOWLEDGE OF RAMARIOPSIS SUBARCTICA (CLAVARIACEAE, BASIDIOMYCOTA)
}

\author{
Marek Halama ${ }^{1}$, Pawel Pech \& Anton G. Shiryaev
}

\begin{abstract}
Although general knowledge of Ramariopsis subarctica Pilát has advanced in the past four decades, there is still little understanding of how the species is distributed and which aspects of the environment determine its distribution. This paper presents the first Polish collections of the species. Hitherto unknown in Poland, $R$. subarctica is reported from two localities in subalpine belts of the West Tatra Mts and Karkonosze Mts. The morphology of newly collected basidiomata of the fungus is described, illustrated and commented, and some basic chemical parameters of its habitat in the Karkonosze Mts are given. All available published material relevant to the global distribution and ecology of $R$. subarctica is reviewed.
\end{abstract}

Key words: arctic and subalpine habitats, biogeography, clavarioid fungi, Clavulinopsis subarctica, distribution, ecology, taxonomy Marek Halama, Museum of Natural History, Wrocław University, H. Sienkiewicza 21, 50-335 Wrocław, Poland; e-mail: marek. halama@uwr.edu.pl

Pawet Pech, Department of Ecology, Biogeochemistry and Environmental Protection, University Wroctaw University, Kanonia 6-8, 50-335 Wrocław,Poland; e-mail: pawel.pech@uwr.edu.pl

Anton G. Shiryaev Institute of Plant and Animal Ecology, Vegetation and Mycobiota Biodiversity Department, Ural Division of the Russian Academy of Science, 8 March str. 202, Ekaterinburg, RU-620144 Russia; e-mail: anton.g.shiryaev@gmail.com

\section{INTRODUCTION}

All members of the genus Ramariopsis (Donk) Corner probably have evolved a biotrophic nutritional mode (Birkebak et al. 2013). Macroscopically the fungi are distinguished by their small to medium-sized, branched or rarely unbranched basidiomata, often with a distinct stem and usually slender, cylindrical branches. Microscopically they can be distinguished mainly on the basis of their echinulate or verrucose to almost smooth spores showing cyanophilous ornamentation, and the presence of clamps at the basidia and hyphae (Knudsen \& Shiryaev 2012b). Fungi of the genus Clavulinopsis Overeem are superficially similar but have smooth basidiospores as a rule (Knudsen \& Shiryaev 2012a) and differ fundamentally in spore wall ultrastructure (Pegler \& Young 1985). Recent phylogenetic analyses of nuclear ribosomal large subunit RNA (nrLSU) sequences support the monophyly of Ramariopsis species with ornamented spores, clamps in trama and branched

\footnotetext{
1 Corresponding author
}

basidiomata (subgen. Ramariopsis), and suggest a paraphyletic origin of the remaining taxa with (almost) smooth spores (Kautmanová et al. 2012). Different generic and infrageneric concepts of $R a$ mariopsis and allied taxa are presented by various authors (e.g., Corner 1950, 1970; Petersen 1978; Jülich 1984, 1985; Hansen \& Knudsen 1997; Krieglsteiner 2000; Olariaga \& Salcedo 2012). Even though molecular methods have been applied, many problems remain unsolved (GarcíaSandoval et al. 2005; Dentinger \& Mclaughlin 2006; Kautmanová et al. 2012). According to Kirk et al. (2008), Ramariopsis is represented by ca 44 species worldwide. As of October 2016, Index Fungorum included 40 valid species in Ramariopsis. In this paper we prefer to use the generic concept of Ramariopsis proposed by Knudsen and Shiryaev (2012b).

Depending on the systematic treatment, 7-9 species of Ramariopsis are known in Europe (Domański 1984; Jülich 1984, 1985; Krieglsteiner 2000). Five species of this genus were 
found previously in Poland: Ramariopsis crocea (Pers.: Fr.) Corner [syn. Clavulinopsis crocea (Pers.) Jülich], R. kunzei (Fr.) Corner [syn. Clavulinopsis kunzei (Fr.) Jülich], R. pulchella (Boud.) Corner [syn. Clavulinopsis pulchella (Boud.) Jülich], R. subtilis (Pers.: Fr.) Corner [syn. Clavulinopsis subtilis (Pers.: Fr.) Corner] and $R$. tenuiramosa Corner (Schröter 1885-1889; Błoński 1890; Wojewoda 1974, 2003; Gumińska 1976, 1981; Kujawa \& Gierczyk 2013; Nowicki \& Gierczyk 2013a, b), all of them recorded from few collections and with only brief descriptions of characteristics.

This paper presents the first Polish records of Ramariopsis subarctica Pilát [syn. Clavulinopsis subarctica (Pilát) Jülich], with comments on the morphological variability of the species and its habitat requirements. We also give detailed information on the occurrence of the fungus along with the accompanying ecological conditions in the Karkonosze Mts, which may be useful in understanding the role, status and ecological requirements of $R$. subarctica in mountainous regions of Central Europe. We also summarize the available ecological and distributional data for $R$. subarctica worldwide.

\section{MATERIAL AND METHODS}

\section{SAMPLING}

Originally this paper was planned to be based on material collected in the Polish part of the Karkonosze Mts, where comprehensive ecological studies of subalpine mires are being conducted by one of the authors (PP). At a late stage of our research, however, it emerged that one earlier gathering of $R$. subarctica originating from the Polish part of the Tatra Mts is housed at SVER herbarium. The specimens from the Tatra Mts represent the first authentic Polish record of $R$. subarctica documented by voucher material. Because the location data for the material from the Tatra Mts is sketchy, and due to time restrictions, it was not possible to compile a dataset describing the Tatra site conditions comparable in quality and scope to the data for the Karkonosze Mts. Here we base the site description and ecological characteristics on the accurate data collected from the Karkonosze Mts. The studied fungi are deposited in the WRSL and SVER collections.

\section{ENVIRONMENTAL STUDY}

\section{IN THE KARKONOSZE MTS}

The investigated mire lies on Równia pod Śnieżką, a subalpine plateau. It is situated at $1437 \mathrm{~m}$ a.s.l. (Ignaciuk 2006). In order to characterize the ecological conditions, water samples were taken from the nearest bog hollows and collected into $100 \mathrm{ml}$ acid-washed polyethylene bottles. Water $\mathrm{pH}$ and conductivity were measured in the field with a HI $991300 \mathrm{pH}-$ meter. Both parameters were standardized at $20^{\circ} \mathrm{C}$. Conductivity was corrected according to Sjörs (1950). The collected water samples were filtered through a glass-fiber filter and stored at $4^{\circ} \mathrm{C}$. We determined the content of $\mathrm{Na}, \mathrm{K}, \mathrm{Ca}$ and $\mathrm{Mg}$ by atomic absorption spectrometry (GBC Avanta), and $\mathrm{NO}_{3}{ }^{-}, \mathrm{NH}_{4}{ }^{+}, \mathrm{PO}_{4}{ }^{3-}$ and $\mathrm{SO}_{4}{ }^{2-}$ with a flow-injection analyzer (FIA analyzer, MLE). In order to characterize the vegetation in which the sampled specimens occurred, we made a phytosociological relevé in a $25 \mathrm{~m}^{2}$ plot, following the methodology of Braun-Blanquet and scoring cover on a 7-point scale. Nomenclature follows Kucharski and Kopeć (2007) for plant communities, Mirek et al. (2002) for vascular plants, Ochyra et al. (2003) for bryophytes, and Index Fungorum (Kirk 2016) for fungi except for Ramariopsis (Knudsen \& Shiryaev 2012b).

\section{MORPHOLOGICAL STUDY}

The description of macro- and micromorphological characters of Ramariopsis subarctica is based on the collection from the Karkonosze Mts (WRSL: PeP2014-001). The macroscopic description is based on study of fresh material and photos. Micromorphological characters were observed from dried material with a Nikon Eclipse E-400 light microscope fitted with a Nikon digital camera (DS-Fi1). Freehand sections of rehydrated pieces of basidiomata were examined in $5 \% \mathrm{NH}_{3} \cdot \mathrm{H}_{2} \mathrm{O}$ reagent with $1 \%$ Phloxine $\mathrm{B}$, and reactions in Melzer's reagent and Cotton Blue were also tested. Image-grabbing and biometric analyses were made with NIS-Elements D 3.1 imaging software. Dimensions of microcharacters were given as (minimum) 10-90 percentile (maximum) values $(\mathrm{n}=$ sample size). Statistical computations employed Statistica (StatSoft). Spore length/width ratio is reported as Q. For basidiospore size measurements, randomly selected mature spores were measured without the hilar appendix and excluding ornamentation. Basidia length was measured excluding sterigmata. Details of hymenial elements were drawn freehand on tracing paper over photographs at $4000 \times$. Morphological terminology follows Hansen and Knudsen (1997). Herbaria abbreviations follow Index Herbariorum (Thiers 2017). 


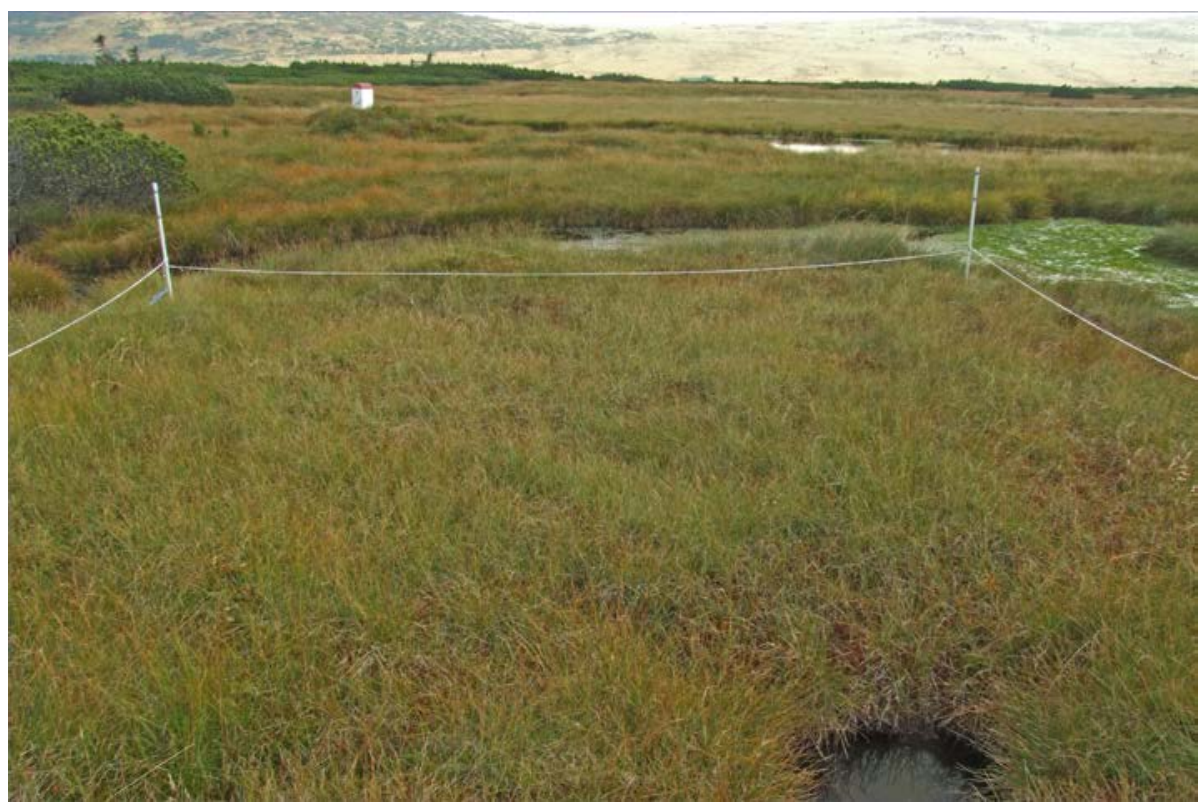

Fig. 1. Locality of Ramariopsis subarctica Pilát on a subalpine plateau in the Karkonosze Mts. The vegetation is dominated by Eriophorum vaginatum and Sphagnum russowii. Równia pod Śnieżką in the Karkonosze Mts, 4 Sept. 2014.

\section{RESULTS}

\section{FLORISTIC CHARACTER AND SITE CONDITIONS IN THE KARKONOSZE MTS}

The vegetation in which Ramariopsis subarctica was recorded presents the typical composition of the Sphagno robusti-Empetrum hermaphroditii community (Fig. 1). Plant species coverage in the relevé was as follows: herb layer c - Eriophorum vaginatum 3, Andromeda polifolia 2, Carex pauciflora 2, Deschampsia flexuosa 1, Vaccinium myrtillus 1, Vaccinium uliginosum + , Oxyccocus palustris + , Calluna vulgaris + ; moss layer $\mathrm{d}-$ Sphagnum russowii 5, Polytrichum strictum 2, Sphagnum lindbergii 2, Sphagnum compactum 1, Plagiothecium laetum + . The herb layer is scattered, with sedges dominating and a small share of dwarf shrubs. Apart from small shares of $S$. lindbergii and $P$. strictum, the moss layer is dominated by $S$. russowii. Both layers are meager, with no more than 14 plant species allogether. The habitat of $R$. subarctica in this area can be characterized as acid and oligotrophic, with water in the surrounding bog hollows at $\mathrm{pH} 3.86$ and conductivity at $3 \mu \mathrm{s}$.
The habitat is poor in nutrients $(\mathrm{K} 0.428 \mathrm{mg} / \mathrm{l}$, $\mathrm{Na} 0.498 \mathrm{mg} / \mathrm{l}, \mathrm{NO}_{3}{ }^{-} 0.005 \mathrm{mg} / \mathrm{l}, \mathrm{NH}_{4}{ }^{+} 0.03 \mathrm{mg} / \mathrm{l}$, $\left.\mathrm{PO}_{4}{ }^{3-} 0.023 \mathrm{mg} / 1, \mathrm{SO}_{4}{ }^{2-} 10.3 \mathrm{mg} / \mathrm{l}\right)$ and minerals (Ca $0.568 \mathrm{mg} / \mathrm{l}, \mathrm{Mg} 0.107 \mathrm{mg} / \mathrm{l})$.

\section{THE SPECIES}

\section{Ramariopsis subarctica Pilát}

Figs $2 \& 3$

Česká Mykol. 25(1): 10. 1971.

Basidiomata 35-55 $\mathrm{mm}$ high and 25-40 $\mathrm{mm}$ wide, solitary, gregarious to caespitose, repeatedly 2-4 times branched (di- to trichotomous) with distinct fasciculate and confluent stems, rather elastic, cream at base, otherwise pale yellow to pale ochraceous; branches $1.6-3.5 \mathrm{~mm}$ thick, with rounded to slightly inflated, blunt tips, smooth to slightly tomentose (main branches). Stem 6-13 $\times 2.0$ $2.5 \mathrm{~mm}$, cylindrical, at base somewhat broader, more or less hidden in mosses, shortly tomentose. Context concolorous. Smell and taste not verified. Basidiospores (5.0) 5.5-7.0 (7.5) × (4.5) 5.0-6.5 (7.5) $\mu \mathrm{m}, \mathrm{Q}=$ (1) 1.0-1.1 (1.3) $(\mathrm{n}=161)$ for the Karkonosze Mts, (5.1) 5.4-7.2 (7.7) $\times(4.2)$ 4.6-6.2 (6.7) $\mathrm{Q}=1.16(\mathrm{n}=30)$ for the Tatra Mts, 


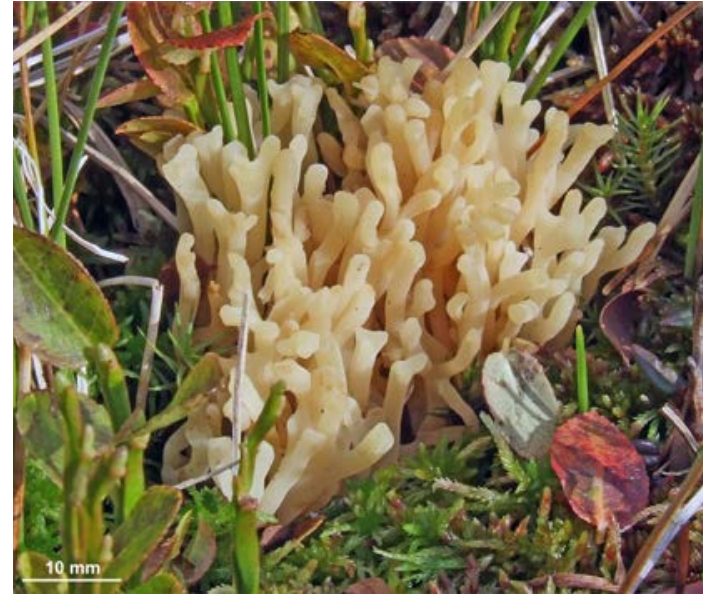

Fig. 2. Ramariopsis subarctica Pilát on a Sphagnum mire. Równia pod Snieżką subalpine plateau in the Karkonosze Mts, 4 Sept. 2014.

globose, subglobose to broadly ellipsoid, mostly 1-guttate, minutely spiny (echinulate) to verruculose, spines to $0.5 \mu \mathrm{m}$ high, cyanophilous, apiculus 0.6-1.3 $\mu \mathrm{m}$ long. Basidia (33.0) 35.0-54.0 (57.5) $\times$ (9) 9-11 (11) $\mu \mathrm{m}(\mathrm{n}=22)$, mostly 4-spored, rarely $2-$ spored, mostly sclerified (in Karkonosze Mts material). Subhymenium and trama in main branches composed of 2-8 $\mu \mathrm{m}$ thick, interwoven to somewhat parallel hyphae. Surface of sterile base covered by repent, cylindrical hyphae $c a 2.0$ $4.5 \mu \mathrm{m}$ thick. Clamp connections present in all tissues.

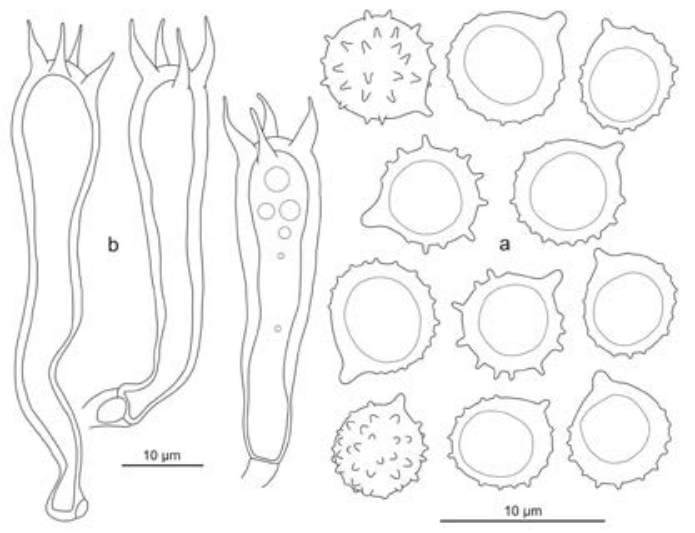

Fig. 3. Micromorphological characters of Ramariopsis subarctica Pilát. A - basidiospores, B - thick-walled (sclerified) basidia (all from WRSL PeP-2014-001).
Specimens examined. POLAND, Sudety Mts, Karkonosze Mts: Równia pod Śnieżką subalpine plateau, on bank of Sphagnum mire among living mosses (Sphagnum russowii, S. lindbergii, Polytrichum strictum) and vascular plants (Andromeda polifolia, Carex pauciflora, Eriophorum vaginatum, Oxyccocus palustris), $50^{\circ} 44^{\prime} \mathrm{N}, 15^{\circ} 41^{\prime} \mathrm{E}, 1430 \mathrm{~m}$ a.s.1., 4 Sept. 2014, P. Pech PeP-2014-001 (WRSL); Central Western Carpathians, West Tatra Mts: in the vicinity of Dziurawe hillside, on bank of moss (also Sphagnum) and ericoid-dominated plant community, on mound rising above community floor, among mosses and creeping dwarf shrubs, together with Clavaria sphagnicola Boud., $49^{\circ} 14^{\prime} \mathrm{N}, 19^{\circ} 53^{\prime} \mathrm{E}, 1650 \mathrm{~m}$ a.s.1. 26 Sept. 2008, A. Shiryaev AGS 26918 (SVER).

AdDITIONAL SPECIMENS EXAMINED. NORWAY, FINNMARK (Nordkapp), 4 Aug. 2013, A. Shiryaev AGS 17032 (SVER); RUSSIA, URAL: Yamal-Nenets Autonomous District (Rai-iz massif): 2 Sept. 2006, A. Shiryaev AGS 203 (SVER); EAST SiBERIA: middle part of Yenisei river basin, 16 Aug. 2015, A. Shiryaev AGS 25951 (SVER); Tunguska River basin, 22 Aug. 2015, A. Shiryaev AGS 12687 (SVER).

\section{Discussion}

\section{TAXONOMY AND MORPHOLOGICAL VARIABILITY}

On the basis of basidiospore ultrastructure studies, no close phyletic relationship between Ramariopsis and 'allied' genera was supported (Pegler \& Young 1985). Therefore, Jülich's (1985) placing of the genus Ramariopsis in synonymy with Clavulinopsis and making of new combinations (including those for Ramariopsis subarctica) does not seem justified. Among European members of Ramariopsis, R. subarctica is recognized morphologically by its pale yellow to ochraceous basidiomata with rather thick branches (2-4 mm diam.) and the comparatively large basidiospores ( $>5.5 \mu \mathrm{m}$ wide on average) (Knudsen \& Shiryaev 2012b). Macroscopically, both Polish collections well fit the published descriptions, and especially correspond to the species concept of Daun and Nitare (1987). Measurements of basidiospores from the Karkonosze Mts (PeP-2014-001), seem to differ from those of the Tatra Mts $(5.1-7.7 \times 4.2-6.7 \mu \mathrm{m}$, $\mathrm{Q}=1.16(\mathrm{n}=30)$, AGS 26918), Finnmark (4.8-7.6 $\times 4.0-7.0 \mu \mathrm{m}, \mathrm{Q}=1.15(\mathrm{n}=30)$, AGS 17032), Ural $(5.3-7.9 \times 4.1-5.8 \mu \mathrm{m} . \mathrm{Q}=1.3(\mathrm{n}=30)$, AGS 
203) and East Siberia $(5.2-8.1 \times 4.0-7.0, \mathrm{Q}=1.25$ $(\mathrm{n}=30)$, AGS 12687) in their more subglobose than broadly ellipsoid shape. Moreover, we frequently observed over-refined (sclerified) basidia in the collection from the Karkonosze Mts. This type of basidia was also reported in $R$. subarctica by Daun and Nitare (1987), but they observed them only occasionally. It is worth noting that the presence of sclerified basidia is a more common phenomenon, occurring not only in Clavariaceae (e.g., Petersen 1971, 1979); it is also known in agarics (Bas 2003), for example.

\section{POPULATION CONDITION, PHENOLOGY}

AND SUBSTRATE SPECIFICITY

Ramariopsis subarctica was found at the end of September 2008 in the Tatra Mts. The material from this area was collected during an ordinary autumn trip to the mountain range. Information on the total number of mature individuals was not then recorded, and care was not taken to record the specific substrate. In the Karkonosze Mts we made a search for $R$. subarctica when the species was noticed by chance in early September 2014 in several groups of basidiomata. In the next year it was only found growing solitary in the area in October. In two years fewer than 10 groups of basidiomata distributed over an area of $\mathrm{ca} 400 \mathrm{~m}^{2}$ were recorded in the peat bog on the Równia pod Śnieżką subalpine plateau. There the occurrence of $R$. subarctica was confined to Sphagnum tufts and slightly raised parts of the mire. Our observations made at the locality revealed that its basidiomata had a preference for decaying thalli of Sphagnum, preferring to grow among Sphagnum russowii and $S$. lindbergii, in the close vicinity of Polytrichum strictum. This confirms the bryophilous character of $R$. subarctica with regard to habitat and substrate preferences as noted by Pilát (1971b) and subsequently supported by others (e.g., Daun \& Nitare 1987; Vašutová et al. 2013). The appearance of $R$. subarctica in this period on mountain ranges in Poland seems consistent with Fenno-Scandinavian phenology, which shows a preference for late summer and early autumn months (Daun \& Nitare 1987).

\section{NOTES ON GENERAL DISTRIBUTION}

AND ECOLOGY

Ramariopsis subarctica is generally known from the Northern Hemisphere only, and it appears to be uncommon but widespread in arctic, tundra and boreal as well as subalpine regions of Asia, Europe and North America (Pilát 1971a, b, 1974; Daun \& Nitare 1987; Shiryaev 2004, 2006; Borgen 2006; Knudsen 2006; Kotiranta et al. 2009; Voitk 2015; Table 1; Fig. 4).

In Europe, R. subarctica has its main occurrence in the northern part of the continent (especially north of $65^{\circ} \mathrm{N}$ ), but it also reaches a certain level of frequency at lower latitudes, where it preferably grows in mountains in the subalpine zone (Daun \& Nitare 1987; Vašutová et al. 2013). This is in line with Pilát's (1971a) characterization of this species as a glacial relict in Central Europe. Until now, the Central European distribution of $R$. subarctica apparently was restricted to very few refugia in the High Tatra Mts (Slovakia: Trojrohé pleso), West Tatra Mts (Poland: Dziurawe hillside), Karkonosze Mts (Poland: subalpine plateau Równia pod Śnieżką; Czech Republic: Prameny Labe, Prameny Úpy) and Hrubý Jeseník Mts (Czech Republic: site Vozka) (e.g., Vašutová et al. 2013; this study). The highest elevation recorded for $R$. subarctica in these regions is in the Tatras (1620-1650 $\mathrm{m}$ a.s.1.). Localities from the Karkonosze Mts are between 1370 and $1440 \mathrm{~m}$ a.s.l., and those from the Hrubý Jeseník Mts come from ca 1300 m (Pilát 1971a, 1974; Fellner \& Landa 1991; Fellner 1996; Vašutová et al. 2013; this study). However, recently $R$. subarctica has also been reported from lowlands $(<100 \mathrm{~m}$ a.s.l.) in Central Europe, from sites near Leck municipality (Süderlügum, Leckfeld-Nord) in the northern part of North Frisia (Schleswig-Holstein) in Germany (Lüderitz et al. 2016). There it grows in mossy and humid shrub habitat (inland dunes) with Calluna vulgaris, Erica tetralix, Empetrum nigrum, Myrica gale and Salix repens (Lüderitz et al. 2016).

In the Tatra Mts, R. subarctica is reported from an open raised bog (with Sphagnum) and from a two-layer habitat formed by mosses (primarily Sphagnum species) and creeping dwarf 
Table 1. Scheme of spatial distribution of Ramariopsis subarctica Pilát by latitudinal/altitudinal zone and geographical region (based on literature records and supplemented by unpublished data).

\begin{tabular}{|c|c|c|c|c|c|c|c|c|}
\hline \multirow{2}{*}{$\begin{array}{l}\text { Geographical } \\
\text { region }\end{array}$} & \multicolumn{8}{|c|}{ Latitudinal/Altitudinal zone } \\
\hline & $\begin{array}{l}\text { high } \\
\text { arctic }\end{array}$ & $\begin{array}{l}\text { low arctic } \\
\text { /subalpine }\end{array}$ & $\begin{array}{l}\text { forest- } \\
\text { tundra }\end{array}$ & $\begin{array}{c}\text { north } \\
\text { boreal }\end{array}$ & $\begin{array}{l}\text { middle } \\
\text { boreal }\end{array}$ & $\begin{array}{c}\text { south } \\
\text { boreal }\end{array}$ & $\begin{array}{l}\text { hemi- } \\
\text { boreal }\end{array}$ & nemoral \\
\hline Greenland & - & $+/-$ & + & & & & & \\
\hline Scandinavia & & $+/+$ & + & + & + & + & + & - \\
\hline Western Europe & & $1-$ & & & & & & + \\
\hline Central Europe & & 1+ & & & & & - & - \\
\hline Eastern Europe & + & +1 & + & + & + & - & - & - \\
\hline Caucasus Mts & & $1+$ & & & & & - & - \\
\hline Ural Mts & & $1+$ & + & + & + & - & - & - \\
\hline Altay-Sayans Mts & & 1+ & & & + & - & - & \\
\hline Western Siberia & - & +1 & + & + & + & - & - & \\
\hline Central Siberia & - & +1 & + & + & + & - & - & \\
\hline Eastern Siberia & & & + & + & + & + & + & \\
\hline Far East (continental) & & +1 & + & + & + & - & - & - \\
\hline Far East (oceanic) & & +1 & + & + & + & + & - & - \\
\hline
\end{tabular}

The compiled division of zonation follows Hämet-Ahti (1981), Bliss (1997), Körner (2003) and Huggett (2004).

shrubs (Vašutová et al. 2013; this study). In the Karkonosze Mts the fungus is known from various (tundra-like) peat bog communities of the class Oxycocco-Sphagnetea (e.g., Chamaemoro-Pinetum mugo and Sphagno robust-Empetretum hemaphroditi) and rarely of the class Scheuchzerio-Caricetea fuscae (Fellner 1996; this study). In the Hrubý Jeseník Mts, $R$. subarctica grows in phytocoenoses of the Andromedo polifoliae-Sphagnetum magellanici association (Vašutová et al. 2013). To complete the comparison, it should be mentioned that $R$. subarctica has frequently been characterized as a typical sphagnicolous and bryicolous species - strictly associated with mire habitats and occurring either among mosses (Sphagnum sp., S. compactum, S. lindbergii, S. russowii, Plagiothecium curvifolium, P. laetum, Polytrichum strictum) or on almost bare soil, often near living mosses and quite a number of accompanying vascular plants such as Andromeda polifolia, Calluna vulgaris, Carex pauciflora, Deschampsia flexuosa, Eriophorum vaginatum, Oxyccocus palustris, Picea abies, Pinus mugo, Rubus chamaemorus, Vaccinum myrtillus and V. uliginosum (Pilát 1971a, 1974; Fellner 1996; Vašutová et al. 2013; this study).

The distribution and ecology of Ramariopsis subarctica in Fenno-Scandinavia (Norway,
Sweden, Finland, Karelia and the Kola Peninsula of Russia) was exhaustively characterized by Daun and Nitare (1987) and supplemented by Kotiranta et al. (2009), Kotiranta and Shiryaev (2013) and Shiryaev (2013a, c). In general, records of the species are distributed across boreal, subalpine and arctic areas of the region. The literature data suggest that records of $R$. subarctica are not evenly distributed over the region. They are most frequent in the subalpine zone of Scandinavian mountains and in the low arctic zone (Daun \& Nitare 1987; Kotiranta et al. 2009; Shiryaev 2013a). The highest records in Fenno-Scandinavia are from ca $600 \mathrm{~m}$ a.s.l. in Sweden to $c a 850 \mathrm{~m}$ a.s.l. in Norway (Daun \& Nitare 1987). The typical habitat of $R$. subarctica in Fenno-Scandinavia seems to be poor Sphagnum mires (with Sphagnum fuscum, S. balticum, S. platyphyllum, S. nemoreum and S. teres), intermediate fens in Pinus-Betula woodlands of the boreal structure type, or treeless areas of hypoarctic tundra type. Ramariopsis subarctica often occurs near living mosses (Calliergon stramineum, Drepanocladus fluitans, Polytrichum strictum, Dicranum angustum, D. elongatum, D. fuscescens, D. scoparium, Pohlia nutans, P. shagnicola) and vascular plants (Baeothryon cespitosum, Betula nana, Drosera rotundifolia, Rubus chamaemorus), 


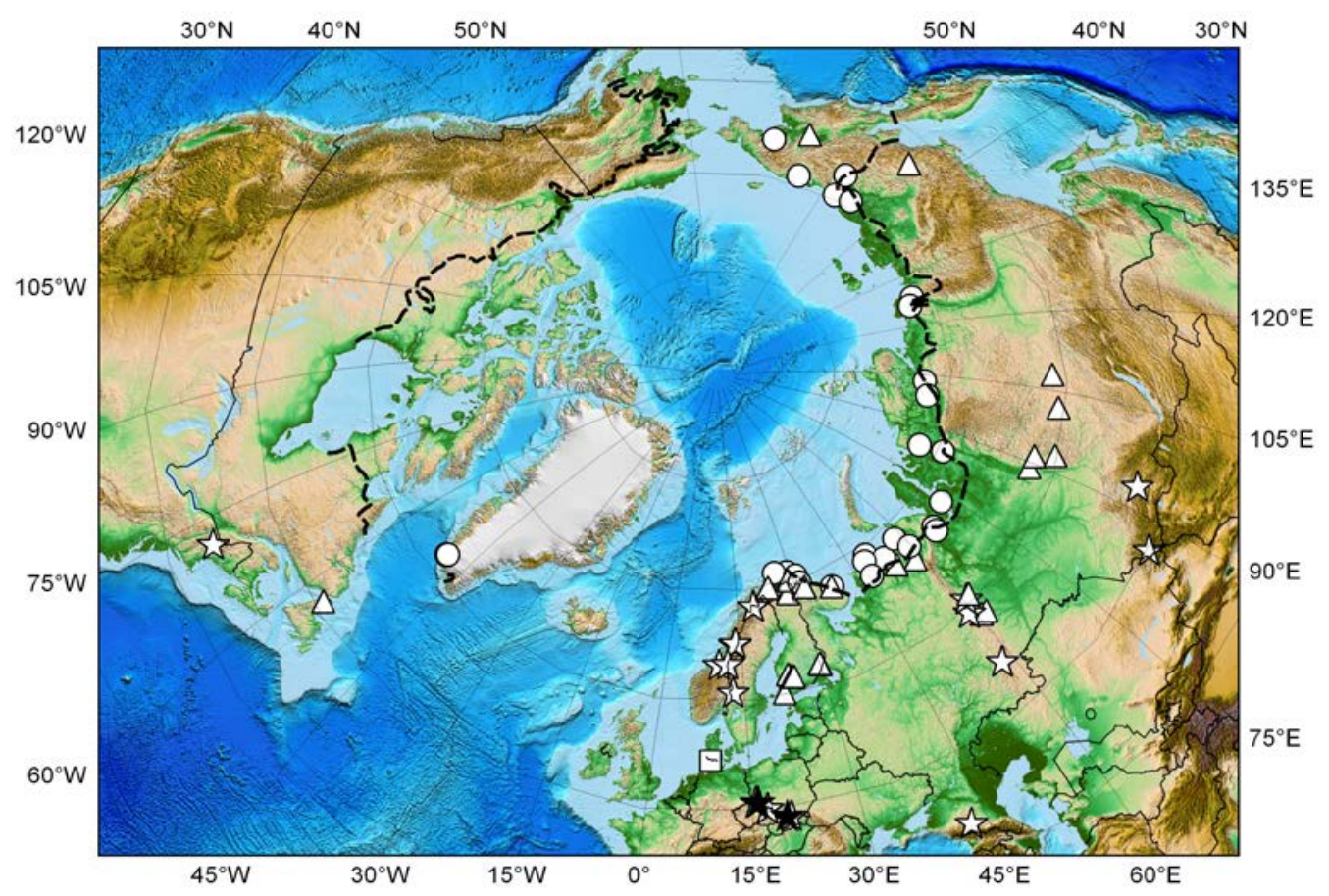

Fig. 4. Map showing world distribution of Ramariopsis subarctica Pilát, based on available literature records and supplemented by current studies. (dashed line - treeline, continuous line - country border, $\bigcirc$ - arctic record, $\triangle-$ boreal record, $\hat{\tau}-$ subalpine record, $\square$ - temperate record, $\downarrow$ - new locality.

including ericoid species (Andromeda polifolia, Calluna vulgaris, Empetrum hermaphroditum). Ecological descriptions also indicate other habitat types such as snowbed vegetation with Salix herbacea and Kiaeria starkei most common (Daun \& Nitare 1987; Walker et al. 2005; Kotiranta et al. 2009; Shiryaev 2013a, c).

Finds of Ramariopsis subarctica from Russian territory (over 40 reports) are the most published material on the species, but that is a small amount of data from such a vast area, and its geographical coverage is patchy due to incomplete penetration of the area for mycological studies. The westernmost finds of $R$. subarctica in Russia are from northern parts of Murmansk oblast (province) (Shiryaev 2009, 2013a), the Nenets Autonomous Region (Shiryaev 2012b), and the northern part of the Komi Republic (Shiryaev 2004, 2006). Further eastward there are records from the Yamal Peninsula (Shiryaev 2008) and Taymyr Peninsula (Shiryaev 2011). The easternmost finds are from the Chukotka Autonomous Region (Shiryaev 2013b), Yakutia Republic (Shiryaev 2012a; Shiryaev \& Mikhalyova 2013) and Magadan oblast (Govorova \& Sazanova 2000) in the Far East. The southern distribution of the species follows records from the Caucasus Mts (Shiryaev 2014), Southern and Central Ural (Bashkiria Republic, Sverdlovsk region) (Shiryaev 2004), West Siberian Plain (Sverdlovsk region) (Shiryaev et al. 2009), through southern Siberia (Altai Mts, Sayan Mts) (Shiryaev 2014) and eastern Siberia (southern and central Krasnoyarsk Krai, northern Irkutsk Oblast) (Kotiranta \& Shiryaev 2015; Shiryaev \& Kudashova 2015; Shiryaev \& Myzika 2015; Shiryaev \& Kotiranta 2015). The available data indicate the highest frequency of $R$. subarctica in northern Russia, close to and beyond the tree line in both the European and Asian portions of low arctic and forest-tundra, while the southern part of its distribution range is rather discontinuous and seems to be shaped by the ecoclimate of higher 
elevations. We suspect that this species is more widespread in the boreal zone than the available records would indicate (cf. Shiryaev \& Mukhin 2010). The finds of $R$. subarctica are widely distributed across European and Asian Russia but appear to be habitat-limited. Although there is relatively little information on the specific vegetation type in which the fungus has been found (arctic tundra, taiga, subalpine tundra) it is by far most frequently recorded in association with more humid habitats (including bogs and margins of mires), preferably on or in mosses (including Sphagnum) (e.g., Shiryaev 2004, 2009; Shiryaev et al. 2009).

The few finds of $R$. subarctica from North America are very recent records from Canada (Voitk 2015) and the USA (Voitk \& Voitk 2015). The latter (without clearly specified ecology and altitude range) is from $\mathrm{Mt}$ Washington (New Hampshire), and the former is from a raised Sphagnum bog in the L'Anse aux Meadows, a famous archaeological site of a Viking settlement on the northernmost tip of the island of Newfoundland (Newfoundland and Labrador Province). Ramariopsis subarctica is also known from Greenland (Borgen 2006; Borgen et al. 2006; Knudsen 2006), where the species was mostly observed within a hyperoceanic zone in dwarf-scrub heaths with Empetrum hermaphroditum, Salix herbacea and S. glauca south of $63^{\circ} \mathrm{N}$.

\section{Conclusions}

The described studies permit some general conclusions regarding the zonal distribution and ecology of Ramariopsis subarctica. Knowledge of the global distribution of $R$. subarctica has advanced during the past four decades but the geographical coverage of research on this species is incomplete. There are still major gaps in our understanding of its biogeographical patterns. For the time being its main documented distribution is in low arctic and forest-tundra areas, but the actual distribution may extend down farther to the southern boreal zone. This fungus reaches with some limited success into high arctic regions in the north and into hemiboreal (rarely nemoral) areas in the south. In the most southern (peripheral) regions, $R$. subarctica is uncommon and restricted to mountainous subalpine belt areas. In general, the distribution of the species seems to be influenced by a combination of factors, the most important of which are its physiological adaptation to relatively cold and humid climate and its association with moss (peat moss) habitats. Ramariopsis subarctica is regarded as a glacial relict of mountain ranges of Central Europe. We found no significant differences in its phenology between the Central European subalpine and the Fenno-Scandinavian subalpine or subarctic sites, with most records being from September. In Poland the recognized distribution of R. subarctica seems incomplete; its occurrence in other peat bogs of mountainous regions of the country seems highly likely, though it has not been found there yet. It remains to be seen whether it occurs in the more southern mountain ranges of Europe.

Our findings confirm prior observations that $R$. subarctica populations from different parts of its geographic range exhibit little variation of basidiomata morphology, though a range of cryptic phylogeographic structure at genetic level cannot be ruled out. Resolution of that question requires additional sequence data and comprehensive molecular studies.

ACKNOWLedgements. We are grateful to Jorinde Nuytinck (Leiden, The Netherlands), Johan Nitare (Jönköping, Sweden) and Renata Woźnica (Kraków, Poland) for their kind help with literature; Matthias Lüderitz (Sibbersdorf, Germany) for making his unpublished information on the distribution of Ramariopsis subarctica in Germany available to us; and the three anonymous reviewers for their critical review of the manuscript. This research was supported in part by the statutory fund of the Museum of Natural History of Wrocław University and by the Russian Foundation for Basic Research (Project No. 16-35-60093 mol_a_dk).

\section{REFERENCES}

Bas C. 2003. A reconnaissance of the genus Pseudobaeospora in Europe II. Persoonia 18(2): 163-199.

Birkebak J. M., Mayor J. R., Ryberg K. M. \& Matheny P. B. 2013. A systematic, morphological and ecological overview of the Clavariaceae (Agaricales). Mycologia 105(4): 896-911. 
BLISs L. C. 1997. Arctic ecosystems of North America. In: F. E. Wielgolaski (ed.), Polar and alpine tundra, pp. 551-684. Elsevier, Amsterdam.

BŁoŃSKi F. 1890. Wyniki poszukiwań florystycznych skrytokwiatowych dokonanych w ciągu lata r. 1889 w obrębie 5-ciu powiatów Królestwa Polskiego Pam. Fizjogr. 10(3): 129-190.

Borgen T. 2006. Distribution of selected basidiomycetes in oceanic dwarf-scrub heaths in the Paamiut area, low arctic South Greenland. In: D. Boertmann \& H. KNUDSEN (eds), Arctic and Alpine Mycology. 6. Meddel. Grønland, Biosci. 56: 25-36.

Borgen T., Elborne S. A. \& Knudsen H. 2006. A checklist of the Greenland basidiomycetes. In: D. BoERTMANN \& H. KNUDSEN (eds), Arctic and Alpine Mycology. 6. Meddel. Grønland, Biosci. 56: 37-59.

Corner E. J. H. 1950. A monograph of Clavaria and allied genera. Oxford University Press, London.

Corner E. J. H. 1970. Supplement to "A monograph of Clavaria and allied genera". Beih. Nova Hedwigia 33: 1-299.

DAUN R. \& NitARE J. 1987. A contribution to the knowledge of Ramariopsis subarctica. Windahlia 16: 89-96.

Dentinger B. T. M. \& Mclaughlin D. J. 2006. Reconstructing the Clavariaceae using nuclear large subunit rDNA sequences and a new genus segregated from Clavaria. Mycologia 98(5): 746-762.

Domański S. 1984. Mała flora grzybów I. Basidiomycetes (Podstawczaki), Aphyllophorales (Bezblaszkowe). 4. Clavariaceae, Clavariadelphaceae, Clavulinaceae, Pterulaceae, Ramariaceae, Stephanosporaceae, Gomphaceae (II), Hericiaceae (II). Państwowe Wydawnictwo Naukowe, Warszawa - Kraków.

FELLNER R. 1996. Register of critically endangered fungi species. Príroda (Praha) 6: 183-195 (in Czech).

Fellner R. \& Landa J. 1991. Arctic and alpine fungi in Czechoslovakia (Abstract of the paper delivered at the $8^{\text {th }}$ Conference of Czechoslovak Mycologists held in Brno (August 28 - September 1, 1989). Česká Mykol. 45(1-2): 35.

García-Sandoval R., Cifuentes J., De Luna E., EstradaTorres A. \& Villegas M. 2005. A phylogeny of Ramariopsis and allied taxa. Mycotaxon 94: 265-292.

Govorova O. K. \& Sazanova N. A. 2000. Clavarioid fungi of Magadan region. Mikol. Fitopatol. 34(5): 8-10.

GumiŃSKA B. 1976. Mycoflora of the Pieniny National Park (Part III). Zesz. Nauk. Uniw. Jagiellon. Prace Bot. 432(4): 127-141 (in Polish with English summary).

GumińsKa B. 1981. Mycoflora of the Pieniny National Park (Part IV). Zesz. Nauk. Uniw. Jagiellon. Prace Bot. 9: 67-81.

Häмeт-Aнті L. 1981. The boreal zone and its biotic subdivision. Fennia 159(1): 69-75.
HANSEn L. \& KNUdSEN H. (eds) 1997. Nordic macromycetes 3. Heterobasidioid, aphyllophoroid and gastromycetoid Basidiomycetes. Nordsvamp, Copenhagen.

Huggett R. J. 2004. Fundamentals of biogeography. $2^{\text {nd }}$ ed. Taylor \& Francis Group, New York.

IGNACIUK M. 2006. Mapa roślinności rzeczywistej subalpejskiego torfowiska na Równi pod Śnieżką w rejonie Srebrnego Upłazu (Karkonosze). Master Thesis, Akademia Rolnicza we Wrocławiu, Wrocław.

JÜLICH W. 1984. Die Nichtblätterpilze, Gallertpilze und Bauchpilze. In: H. GAms (ed.), Kleine Kryptogamenflora IIb/1. Basidiomyceten, pp. 1-626. Gustav Fischer Verlag, Stuttgart.

JÜLICH W. 1985. Bemerkungen zu Clavulinopsis und Ramariopsis. Int. J. Mycol. Lichenol. 2(1): 119-122.

KaUtmanová I., AdAMČíK S. \& JANČOvičová S. 2012. Revision of taxonomic concept and systematic position of some Clavariaceae species. Mycologia 104(2): 521-539.

KIRK P. I. 2016. Index Fungorum. [10 October 2016]. http:// www.indexfungorum.org/Names/Names.asp.

Kirk P. M., Cannon P. F., Minter D. V. \& Stalpers J. A. 2008. Ainsworth \& Bisby's Dictionary of Fungi. $10^{\text {th }}$ ed. CAB International, Wallingford.

KNUDSEN H. 2006. Mycology in Greenland. In: D. BoERTMANN \& H. KNUDSEN (eds), Arctic and Alpine Mycology 6. Meddel. Grønland, Biosci. 56: 7-16.

KnUdSen H. \& Shiryaev A. 2012a. Clavulinopsis Overeem. In: H. KNUdSEN \& J. Vesterholt (eds), Funga Nordica. Agaricoid, boletoid, clavarioid, cyphelloid and gastroid genera, pp. 247-248. Nordsvamp, Copenhagen.

Knudsen H. \& Shiryaev A. 2012b. Ramariopsis (Donk) Corner. In: H. Knudsen \& J. Vesterholt (eds), Funga Nordica. Agaricoid, boletoid, clavarioid, cyphelloid and gastroid genera, pp. 249-251. Nordsvamp, Copenhagen.

Kotiranta H. \& Shiryaev A. 2013. Notes on Aphyllophoroid fungi (Basidiomycota) in Kevo, collected in 2009. Kevo Notes 14: 1-22.

Kotiranta H. \& Shiryaev A. G. 2015. Aphyllophoroid fungi (Basidiomycota) in Tunguska River basin, central East Siberia, Russia. Karstenia 55: 25-42.

Kotiranta H., SaARenoksa R. \& KytövuORi I. 2009. Aphyllophoroid fungi of Finland. A check-list with ecology, distribution, and threat categories. Norrlinia 19: 1-223.

KöRNER C. 2003. Alpine plant life - functional plant ecology of high mountain ecosystems. $2^{\text {nd }} \mathrm{ed}$. Springer-Verlag, Berlin.

Krieglsteiner G. J. 2000. Cantharellales Gäumann s.1. In: G. J. KrieglSteiner (ed.), Die Großpilze Baden-Württembergs. 2. Ständerpilze: Leisten-, Keulen-, Korallen- und Stoppelpilze, Bauchpilze, Röhrlings- und Täublingsartige, pp. 7-102. Eugen Ulmer GmbH \& Co., Stuttgart. 
KuCHARSKi L. \& Kopeć D. 2007. Review of raised bog communities from Oxycocco-Sphagnetea distinguished in Poland. Wiadom. Bot. 51(3-4): 21-28 (in Polish with English summary).

Kujawa A. \& GierczyK B. 2013. Register of protected and endangered fungi species in Poland. Part VII. A list of species recorded in 2011. Przeglad Przyrodniczy 24(2): 3-42 (in Polish).

Lüderitz M., Kamke M., Specht P., Ludwig E., LehmanN H., Schubert H., Richter H. \& Richter U. 2016. Ergebnisse des 4. und 5. Dünenpilzworkshops. Z. Mykol. 82(2): 355-448.

Mirek Z., PięKoś-Mirkowa H., ZająC A. \& ZająC M. 2002. Flowering plants and pteridophytes of Poland. A checklist. W. Szafer Institute of Botany, Polish Academy of Sciences, Kraków.

Nowicki J. \& GIERCZYK B. 2013a. Bio-forum.pl: Ramariopsis crocea. [September 2016]. http://www.bio-forum.pl/messages/33/600330.html.

NOWICKI J. \& GIERCZYK B. 2013b. Bio-forum.pl: Ramariopsis tenuiramosa. [September 2016]. http://www.bio-forum.pl/ messages/33/620826.html.

Ochyra R., Żarnowiec J. \& BednareK-Ochyra H. 2003. Census catalogue of Polish mosses. Institute of Botany, Polish Academy of Science, Kraków.

Olariaga I. \& Salcedo I. 2012. New combinations and notes in clavarioid fungi. Mycotaxon 121: 37-44.

Pegler D. N. \& Young T. W. K. 1985. Basidiospore structure in Ramariopsis (Clavariaceae). Trans. Brit. Mycol. Soc. 84(2): 207-214.

Petersen R. H. 1971. Notes on clavarioid fungi. IX. Addendum to Clavulinopsis in North America. Persoonia 6(2): 219-229.

Petersen R. H. 1978. Notes on clavarioid Fungi. XV. Reorganization of Clavaria, Clavulinopsis and Ramariopsis. Mycologia 70(3): 660-671.

Petersen R. H. 1979. Notes on clavarioid fungi. XVII. Clavulinopsis taxa in southeastern Australia. Sydowia 32: 209-223.

PiLÁt A. 1971a. Beitrag zur Kenntnis der tschechoslowakischen Clavariaceen sensu ampl. Sborn. Nar. Mus. v Praze, Rada B, Prir. Vedy 27(4): 133-176.

PILÁt A. 1971b. Species nova turficola generis Ramariopsis (Donk) Corner: Ramariopsis subarctica sp. nov. Česká Mykol. 25(1): 10.

PILÁt A. 1974. Ramariopsis subarctica Pilát in Montibus Corconticis Sudetorum lecta. Bull. Mens. Soc. Linn. Lyon. Numéro Special 43: 339-342.

SCHRÖter J. 1885-1889. Die Pilze Schlesiens. 3(1). Kryptogamen-Flora von Schlesien. 3. J.U. Kern's Verlag, Breslau.

Shiryaev A. G. 2004. Clavarioid fungi of the Urals. I. Boreal forest zone. Mikol. Fitopatol. 38(4): 59-72.
ShIRYAEv A. G. 2006. Clavarioid fungi of the Urals. III. Arctic zone. Mikol. Fitopatol. 40(4): 294-306.

ShiryaEv A. G. 2008. The clavariod fungi of the Yamal Peninsula. Novosti Sist. Nizsh. Rast. 42: 130-141 (in Russian with English summary).

Shiryaev A. G. 2009. Clavarioid fungi of the tundra and forest-tundra zones of Kola Peninsula (Murmansk Region). Novosti Sist. Nizsh. Rast. 43: 134-149 (in Russian with English summary).

ShIRYAEV A. G. 2011. Spatial structure of clavarioid fungi biota in tundra zone of Taimyr Peninsula. Novosti Sist. Nizsh. Rast. 45: 133-145 (in Russian with English summary).

Shiryaev A. G. 2012a. Biodiversity of clavarioid fungi in the tundra zone of Yakutia. Novosti Sist. Nizsh. Rast. 46: 120-127 (in Russian with English summary).

ShiryaEv A. G. 2012b. Clavarioid fungi of the Kanin-Pechora tundra. Mikol. Fitopatol. 46(4): 257-263 (in Russian with English summary).

ShIRYAEV A. G. 2013a. The clavarioid mycobiota of Northern Fennoscandia: Is it a tundra or a boreal structure? Trudy Karel'skogo Nauchnogo Tsentra Rossiyskoy Akademii Nauk, Biogeografiya 2(14): 55-64 (in Russian with English summary).

ShiryaEv A. G. 2013b. Geographical specificy of the tundra and boreal biota of clavarioid fungi in Chukotka. Byull. Moskovsk. Obshch. Isp. Prir. Otd. Biol. 118(5): 67-79.

Shiryaev A. G. 2013c. Spatial heterogeneity of the species composition of a clavarioid fungi's complex in the Eurasian arctic. Contemporary Problems of Ecology 6(4): 381-389.

Shiryaev A. G. 2014. Spatial differenciation of clavarioid mycobiota of Russia: ecologo-geographical aspect. $\mathrm{PhD}$ Thesis, Moscow State University, Moscow (in Russian with English summary).

Shiryaev A. G. \& Kotiranta H. 2015. Aphyllophoroid fungi (Basidiomycota) of the middle part of Yenisei River basin, East Siberia, Russia. Karstenia 55: 43-60.

Shiryaev A. \& Kudashova N. N. 2015. Biological diversity of aphyllophoroid fungi in the reserve of Tunguska (Krasnoyarsk region, Evenki district). Vestnik. Irkutskiy Gosudarstvennyy Agrarnyy Universitet im. A. A. Ezhovskogo 71: 69-85 (in Russian with English summary).

ShiryaEv A. G. \& Mikhalyova L. G. 2013. Aphyllophoraceous fungi (Basidiomycetes) in the tundra and forest-tundra of the Lena River Delta and Novosibirsk Islands (Arctic Yakutia). Novosti Sist. Nizsh. Rast. 47: 155-166 (in Russian with English summary).

Shiryaev A. \& MyziKa S. M. 2015. Aphyllophorales fungi of Central Siberia: structure of local complexes in middle taiga. Vestnik. Irkutskiy Gosudarstvennyy Agrarnyy Universitet im. A. A. Ezhovskogo 68: 63-75 (in Russian with English summary). 
Shiryaev A. G. \& Mukhin V. A. 2010. Clavarioid-type fungi from Svalbard: Their spatial distribution in the European High Arctic. N. Amer. Fungi 5(5): 67-84.

Shiryaev A. G., Kotiranta H., Mukhin V. A., Stavishenko I. V. \& Ushakova N. V. 2009. Aphyllophoroid fungi of Sverdlovsk region, Russia: biodiversity, distribution, ecology and the IUCN threat categories. Goshchitskiy Publisher, Ekaterinburg.

SJöRS H. 1950. On the relation between vegetation and electrolytes in north Swedish mire waters. Oikos 2(2): 241-258.

Thiers B. 2017. Index Herbariorum: A global directory of public herbaria and associated staff. New York Botanical Garden's Virtual Herbarium [continuously updated]. http:// sweetgum.nybg.org/science/ih/.

VAŠUtoví M., DvoŘÁK D. \& BerAn M. 2013. Rare macromycetes from raised bogs in the Hrubý Jeseník Mts. (Czech Republic). Czech Mycol. 65(1): 45-67.
VoITK A. 2015. Ramariopsis subarcitica first report in North America. Omphalina 6(5): 10-11.

Voitк A. \& Vortк M. 2015. Mt Washington faerie. Omphalina 6(6): 9-13.

Walker D. A., Raynolds M. K., Daniëls F. J. A., Einarsson E., Elvebakk A., Gould W. A., Katenin A. E., Kholod S. S., Markon C. J., Melnikov E. S., Moskalenko N. G., Talbot S. S., Yurtsev B. A. \& The other members OF THE C.T. 2005. The Circumpolar Arctic vegetation map. J. Veg. Sci. 16(3): 267-282.

Wojewoda W. 1974. Macromycetes of the Ojców National Park. Acta Mycol. 10(2): 181-265 (in Polish with English summary).

Wojewoda W. 2003. Checklist of Polish larger Basidiomycetes. W. Szafer Institute of Botany, Polish Academy of Sciences, Kraków. 